\title{
Strategic Planning and Business Performance of Micro, Small and Medium-Sized Enterprises
}

\author{
Skokan Karel, Pawliczek. Adam, Piszzzur Radomír
}

\begin{abstract}
This paper deals with issues of strategic management, particularly strategic planning and its beneficial effect on the overall performance of businesses. It is based on empirical results of the original research study called Adaptability of Enterprises to Contemporary Economic Conditions in Years 2007-2012 performed via questionnaire survey in three rounds during years 2011, 2012 and 2013. The analyses presented in the paper were conducted on the second round sample of 677 organizations operating mostly in the SME sector in the Czech and Slovak Republic. The interdependence between the level of strategic planning (existence of strategy in the form of written document and its extent) and enterprise performance criteria (turnover, costs, profit, EVA, investments, period of arranged contracts) is examined with the use of four hypotheses. The results are commented and discussed. The outcome is the apparent positive impact of full strategic document on the performance criteria of the businesses.
\end{abstract}

Keywords: strategic planning, business strategy, performance criteria, questionnaire research, SMEs JEL Classification: D22, L21, L25, R11

\section{INTRODUCTION}

During the last years, Czech and Slovak enterprises can be characterized by the effort to adapt on new emerging conditions which appeared after the outbreak of the global economic crisis in around 2007. Although economic revival is wistfully awaited, the recession still exists in the Czech economy with often fatal influence on many unstable enterprises. In these turbulent times strategic management and planning takes an important role, however is more or less neglected especially by the SMEs sector managers. And it is insistent more than ever to revise business goals and formulate them clearly to be able to steer the craft of business through riffles of uncertainty and variable conditions.

The process of strategic management includes usually basic and periodically repeating set of consecutive stages, through which the companies create, implement and control achievement of the long-term business objectives (Johnson, 2006; David, 2013):

1. strategic analyses,

2. formulation of strategy,

3. strategy implementation,

4. feedback, ex-post evaluation and correction.

Permanent implementation of this process together with recent updating of the strategy and reasonable planning period brings often the strategic predominance for the company. 
Many researchers in the field of strategic management confess that this area is still paid by company management little attention. Managers often do not realize the significance and importance of strategic approach for business or they are not able to establish it. They are often overloaded by operational tasks that arise from everyday business practices and the bird's eye view to see the goals and challenges they face in a broader context is withdrawn from them. Moreover they are often not able or competent to carry out necessary inner-outer management analyses.

The paper presents the findings of extensive research that show how important strategic management and planning are and can help to strengthen the awareness of strategic management to Czech and Slovak management community.

\section{THEORETHICAL BACKGROUND}

Although big companies create enormous output for the vitality of national economy in the changing global economic environment, which is characterized by continuous structural changes and enhanced competitive pressures, the important role of small and medium-sized enterprises (SMEs) is still increasing.

\subsection{Economic importance of Small and Medium Enterprises (SMEs) sector}

The sector of SMEs occupies in the economy very important place as the driving force of business, growth, innovation and competitiveness. SMEs sector plays decisive role in job creation and generally is a factor of social stability and economic development. By Ministry of Industry and Trade (MPO, 2012), in the Czech Republic SMEs contribute to employment 60,9\% which is 1,856 million jobs and 49,5\% of total output of business community. The SMEs sector in the Czech Republic participated in 2011 in the total exports of 51,5\%, i.e. 1478 billion CZK. The share of SMEs in total import in 2011 amounted to 56,6 \%, i.e. 1515 billion CZK.

In the European Union SMEs are the backbone of the economy, employing more than 87 million EU citizens. SMEs generate every second newly created job and produce nearly $60 \%$ of the GDP of the European Union (EC, 2012). However, SMEs were increasingly afflicted by the crisis. Research shows that only $50 \%$ of businesses survive the first five years of its existence and economic crisis definitely decreases this number. Estimated full 1,7 million jobs were lost in 2009 due to insolvency of companies, what represents an increase of $22 \%$ compared to 2008.

\subsection{Strategic planning and management of SMEs}

In the SME sector, the role of management is always derived from the size of the organization and the role of the owner. Primary importance of management function is not by Zich (2010) determined so much by the fact that management has unquestioned responsibility for the formulation and implementation of strategy as the assumption that competitiveness is created or at least affected by all management activities in terms of features and functions of management with a focus on resources, competencies and processes. Size of organization however, does not necessarily reduce the level of strategic management importance. In large enterprises responsibility for strategic management takes the entire department of analysts and competent managers, but in small businesses the primarily strategic manager role takes usually the owner. 
According to Volberda et al. (2010) strategic management based on long-term forecasts, helps the company to anticipate future challenges and opportunities. The term strategy is closely linked with the objectives that it tracks. According to Kotler and Keller (2007) strategy should express the basic idea of which way the company goals will be achieved. The importance of strategy for innovation development and competitiveness of firms emphasized many authors in the last years, e.g. Glaister (2008), Skokan (2010), Volberda et al. (2010), David (2013).

The application of strategic management in the Czech business environment is still at a very low level. The ability to succeed in constantly changing environment demands highly competent management in which Czech companies have, by Mallya (2007) significant gaps especially in terms of lack of strategic thinking and awareness.

Generally we can divide companies (including both SMEs and big firms) in terms of business strategy development into three categories (Šebestová, Nowáková 2013):

1. Companies that have well-planned and detailed written primary strategic document (business plan). Such document deals with important areas of enterprise organization as human resources, market analyses and marketing goals, product development and innovation, technologies of production and services, logistics, quality and environment, budgeting, financing and payback, time schedule, risk evaluation, etc. Detailed strategic document should have utilized modern management methods and techniques as PEST, Porter five forces, marketing mix, SWOT and others. The strategic document covers future period of at least three years and is often compared with real situation and updated (at least once a year).

2. Companies that have strategic document drawn up in some written but concise form, with insufficient details in all important chapters. Many enterprises briefly address just mission and vision and some partial strategic issues, such as production, marketing or finances; however other important chapters stay unelaborated.

3. Companies that have no written strategic document. There is never clear if the strategy is kept in mind of top management (e.g. alone self-employed entrepreneurs), some pieces are subject of company culture or does not exist at all.

These three categories of strategies are further used in the paper. Organizations that do not have written strategy are unfortunately still the most populated group (Pawliczek et al. 2011). But it is exactly strategic business management that can provide an organization the advantage in the competition battle. Johnson and Scholes (2006) present that the business strategy should provide specific business competitive advantage.

Benefits of the introduction of strategic management in small and medium-sized enterprises describe Analoui and Karami (2003) in the following points. They

- help to understand the current situation in which the company is located,

- give a clear view of the vision, mission of the company,

- determine the strengths and weaknesses, emphasizing those that are strategically important for the company's activities,

- contribute to setting the right goals of the company, 
- allow the company to be more active,

- prepare the organization to be able to deal with expected and unexpected problems,

- create a background for communication management in the organization,

- evaluate environmental issues and its changes,

- allow the introduction of ethics and corporate social responsibility in the strategic process.

Andersen's empirical study (Andersen, 2000, p. 196) provides evidence that strategic planning (that emphasizes elements of the conventional strategic management process) is associated with higher performance in all the industrial environments studied. The performance effect of strategic planning does not vary significantly between the different industry groups. Hence, strategic planning is an important performance driver in all industrial settings, and enhances both economic performance and organizational innovation. According to Song (2011) the empirical evidence suggests that more strategic planning and more new product development projects lead to better firm performance. Although strategic planning is a process for anticipating environmental turbulence, the logical sequential process often prescribed in the literature is not sufficient to influence performance. Flexibility in decisions is needed to change operational issues, such as products and services or their production and to change financial issues, such as capital and gearing in order to impact on financial performance (Rudd et all, 2008). We accept this commentary and search also in enterprises for last strategy update.

Strategic planning is difficult and underestimated task of management which thoroughness mirrors in long-term performance of enterprises. Further parts of the paper discover evidence of this phenomenon in Czech and Slovak milieu.

\subsection{Goals and hypotheses}

Based on current issues discussed above, the following hypotheses were formulated:

- H1: Bigger companies pay more attention to strategic management and have more often made thorough strategy formalized in strategic document.

- H2: Existence of detailed written strategy of the organization has definite positive effect on selected business performance indicators.

- H3: Existence of any written strategy (concise - not sufficiently detailed) of the organization has definite positive effect on selected business performance indicators.

- H4: Selected data group criterion "number of employees" is in concordance to Chi-squared or Poisson distribution according to Pearson's chi-squared test of goodness of fit.

The validity of hypotheses is investigated later by empirical evaluation of relevant questionnaire criteria.

\section{METHODOLOGY}

The chapter presents basic characteristics of research methodology used in course of preparation of the article. 


\subsection{Original questionnaire research}

Company research "Adaptability of entrepreneurship" (second round) was realized during spring 2012. Total number of 722 companies active in Czech and Slovak Republic in time period 2009-2011 was subject of interest (SMEs are creating 89\% of sample group in accordance with number of employees' criterion). Interview protocol included controlled dialogue of a questioner with an enterprise owner, an executive manager or a top manager, so the collected data have the character of expert guess opinion. Initial sample size 722 companies were filtered and reduced to 677 credible items (group of all firms). The questionnaire form also includes nondisclosure statement to provide business and privacy protection. Moreover data were analysed anonymously and published as only no-name data.

Data reliability is assured (1) by authorization (contact person, signature, stamp), (2) by subjective questioner relevance evaluation, partially (3) by internet verification and (4) by statistical evaluation. Questionnaire was focused on seven areas of interest and 14 of total 61 questions were evaluated in the paper. Each part had a space for possible comment or further narrative information about questions asked.

The following questions/criteria were evaluated in presented paper. Numbering of questions corresponds the one used in the questionnaire.

Enterprise identification (part A):

- A2: Legal form of a company (self-employed entrepreneur, LLC, PLC, other: text).

- A5: Main economic activity of entrepreneurship: NACE Classification (nn).

- A6: Place of business - town/country (text, CZ, SK).

- A7: Average number of employees in determined period: $(0,1-10,11-50,51-100,101$ $-250,251+)$.

- A8: Average annual turnover (revenue) in the years 2009-2011: (<1 mil., 1 mil. to 10 mil., 10 mil. to 100 mil., 100 mil. to 250 mil., 250 mil. to 1 bn $>1$ bn. CZK) with respect to approximate exchange rate to $€:(<40.000,40.000$ to $400.000,400.000$ to 4 mil., 4 mil. to 10 mil., 10 mil. to 40 mil., $>40$ mil. EUR).

Enterprise strategic management (part B):

- B1: What form of strategic document - business plan has the company got: not written, written but only concise, written detailed - full strategic document, other: text (for explanation see par. 2,2).

- B2: Date of last significant actualization of strategic document: (mm.yyyy).

- B3: Planned period considered by the strategic document: (<1year, $1-3$ years, 3 - 5 years, 5 -10 years, $>10$ years).

Economic and financial trends of business, risk management (part $\mathrm{C}$ ):

- C1: How did period 2009-2011 influence annual turnover (revenue)? (growth more than $30 \%$, growth up to $30 \%$, no change, fall up to $30 \%$, fall more than $30 \%$ ).

- C2: How did determined period influence company costs? (growth $>30 \%$, growth up to $30 \%$, stagnation, fall up to $30 \%$, fall $>30 \%$ ). 
- C3: How did determined period influence company profit? (growth $>30 \%$, growth up to $30 \%$, stagnation, fall up to $30 \%$, fall $>30 \%$ ).

- C4: How did determined period influence company property (investments)? (growth $>30 \%$, growth up to $30 \%$, stagnation, fall up to $30 \%$, fall $>30 \%$ ).

- C12: How did determined period influence EVA (economic added value)? (growth $>30 \%$, growth up to $30 \%$, stagnation, fall up to $30 \%$, fall $>30 \%$ ).

- C6: How long in advance are the company contracts usually arranged? (max. 1 week, max. 1 month, max. 3 months, max. half a year, 1 year or more).

Data were processed by Microsoft Excel ${ }^{\circledR}$ and IBM SPSS ${ }^{\circledR}$. Row diagrams were created as a characterization of particular data groups; their maxima, minima were deduced and difference calculated. Pearson's chi-squared test of goodness of fit was calculated. Analyses, results and discussion are presented later.

\section{RESULTS AND DISCUSSION}

In this chapter obtained data from different points of view are characterized at the beginning. Most important charts and tables are presented and commented then; first results concerning the form of strategy versus company size (number of employees and annual turnover) and legal status and later results concerning the form of strategy versus six selected performance parameters.

\subsection{Basic important characteristics of the data sample}

Analyses of the bulk sample (all firms group including 677 enterprises) and their attitude to business strategic management brought following information.

A. (QA6) From the geographical point of view 89,1\% (603 enterprises) of all firms group (counting 677 enterprises) are settled in the Czech Republic; 10,9\% (74 enterprises) are in the Slovak Republic. The 63,5\% (430 enterprises) are from Moravia-Silesia region, at the same time 19,1\% (129 enterprises) are from Ostrava - capital city of Moravia-Silesia region, 8,4\% (57 enterprises) are from Karviná - seat of School of Business Administration; 3,8 \% from city of Třinec and 3,1 \% from city of Frýdek-Místek - other important industrial centres of Moravia-Silesia region. Furthermore 5,0 \% (34) questioned enterprises are from Prague, capital of the Czech Republic. Overall 79,6\% of enterprises are from Moravia regions and 9,5 \% from Bohemia regions including Prague.

B. (QA5) Concerning structure of economic activity branches according to NACE-CZ industry classification we can say, that almost a quarter (24\%) of questioned enterprises were active in section C - Manufacturing. Than very closely with $23 \%$ the section $\mathrm{G}-$ Wholesale and retail trade; repair of motor vehicles and motorcycles is covered. On third place is the section F - Construction (13\%). No other sections exceed $7 \%$ and all other sections together create $40 \%$ of all firms group.

C. (QB1) Biggest group of $42 \%$ enterprises have some written strategic document in brief but concise form, $41 \%$ of enterprises have not written strategy at all and only $17 \%$ have detailed 
written strategic document. This characterizes general underestimation of strategic management significance.

D. (QB3) What is the usual period covered by strategy? The 566 enterprises answered that question ( $84 \%$ of all firms group). We found that biggest group of enterprises (43\%) is able to foresee and plan situation 1 to 3 years forward, $30 \%$ only 1 year forward and $17 \%$ maximally 3 to 5 year forward. It means that no more than $10 \%$ enterprises (it is $8 \%$ of all firms group including 677 enterprises) are able to look out over 5 years forward ( 5 to 10 years: $5 \%$; over 10 years: $5 \%$ ). This is perfectly consistent with overall political background in the Czech Republic - no visions and plans longer than to next elections; however from global strategic point it is simply insufficient. Major players draw cards with much longer perspective.

E. (QB2) Questioning of last strategy update brought these results: Only 434 enterprises - 64 $\%$ of all firms group answered that question. We found, that $44 \%$ updated strategy in 2011 (two years ago since questioning date), $19 \%$ in 2010 (three years ago) and $11 \%$ in 2012 (a year ago). Totally $74 \%$ of enterprises updated their strategy not later than three years ago (it is 47 $\%$ of all firms group including 677 enterprises). Next $26 \%$ updated strategy like that: 2009 (7 $\%), 2008$ (6\%), 2007 (4\%), and earlier $9 \%$.

Following charts (Figures 1 and 2) characterize researched enterprises regarding size from the point of view of two pertinent parameters - number of employees (figure 1) and average annual turnover (Figure 2). Furthermore we can clearly see how size matters the diligence of strategic planning reflecting the form of primary strategic document or business plan (not written, written concise or written detailed).

The Figure 1 shows, that more than $51 \%$ of questioned enterprises (all firms group) are so called "micro" enterprises with no more than 10 employees, approximately $24 \%$ are "small" enterprises up to 50 employees and approximately $14 \%$ are "medium" enterprises - all together 89 $\%$ are SMEs (small and medium - incl. micro enterprises up to 250 employees). Only about $11 \%$ of researched group create big enterprises with above 250 employees.

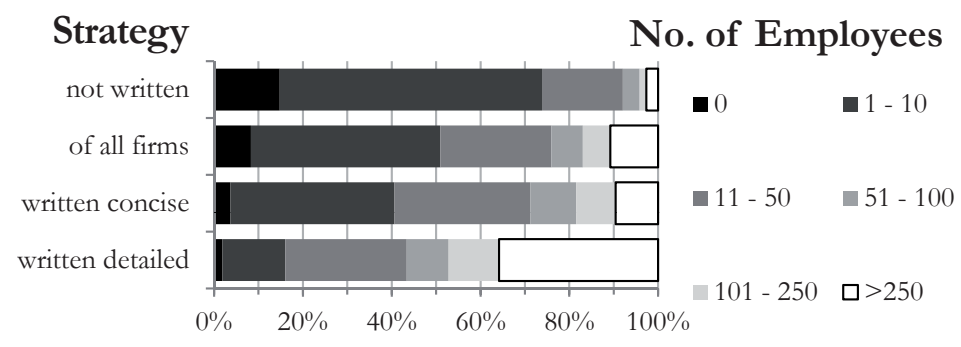

Fig. 1 - Strategy form and enterprise size by number of employees (QB1/QA7). Source: own processing.

Figure 2 shows that approximately $85 \%$ of researched enterprises (all firms group) are "micro and small" enterprises with average annual turnover up to $250 \mathrm{mil}$. CZK (10 mil. EUR) and only about $6 \%$ are big enterprises with average annual turnover over 1 bill. CZK (40 mil. EUR). By the way, these points out, that relatively high number of employees does make relatively low average turnover - however that is not in the focus of the paper. 


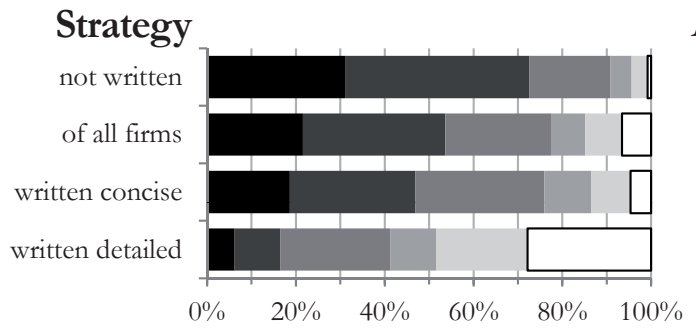

Ann. Turnover

- <1 mil.

- <10 mil.

- <100 mil.

- $<250$ mil.

n $<1$ bill.

$\square>1$ bill.

Fig. 2 - Strategy form and enterprise size by average annual turnover (QB1/QA8). Source: own processing.

Most important finding of Figure 1 and 2 can be seen in percentage of enterprises with different diligent form of strategy regarding their size. Almost $35 \%$ of enterprises according to number of employees or $28 \%$ according to annual turnover who stated to have detailed written strategy are big enterprises in comparison to 1 to $3 \%$ who stated to have not written strategy and who are big enterprises. In other hand $95 \%$ of enterprises (according to both employees and turnover) who stated not to have written strategy are "micro and small" and only 51 to $53 \%$ who stated to have detailed written strategy and who are "micro and small" enterprises. The "medium" enterprises seem to be more diligent than "micro and small" and less than "big" - approximately $20 \%$ with detailed strategic document (e.g. business plan) in comparison to approximately 3 to $5 \%$ of not written strategy.

In the light of recent findings we can accept hypothesis H1: Bigger companies pay more attention to strategic management and have more often made full detailed strategy (strategic document).

Further supplemental point of view to the size is the legal form of researched enterprises regarding form of strategy (Figure 3).

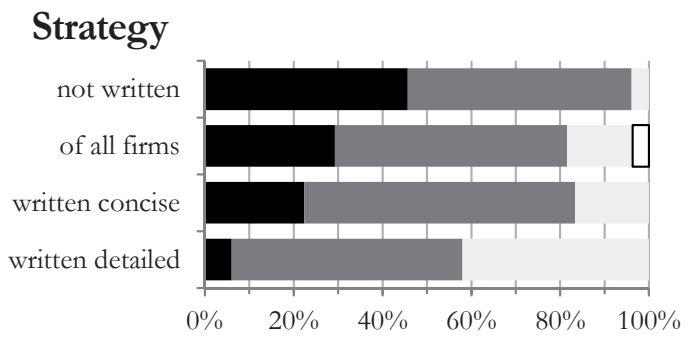

\section{Legal Status}

- self employed

- LLC

PLC

$\square$ other

Fig. 3 - Strategy form and enterprise legal form (QB1/QA2). LLC - limited liability company, PLC - public limited company. Source: own processing.

We observed that almost $45 \%$ of enterprises with no written strategy are self-employed entrepreneurs, $50 \%$ are LLCs (limited liability companies) and only about up to $5 \%$ are PLCs (public limited companies). On other side we see reversed situation: almost $42 \%$ of enterprises with detailed written strategy are PLCs, $50 \%$ are LLCs and only $5 \%$ are self-employed entrepreneurs. 


\subsection{Trends of performance parameters in relation to the form of strategy}

Interesting results can be seen in following charts (Figures 4 to 6 ) in the comparison of selected enterprises performance indicators (turnover, costs, profit) in connection with the strategy form and change category. Research has generally shown that organizations that dealt with the strategy well mostly experienced positive development in all criteria in the years 2009-2011. Following figures show that the positive development of all parameters recorded most organizations that paid attention on strategic document seriously.

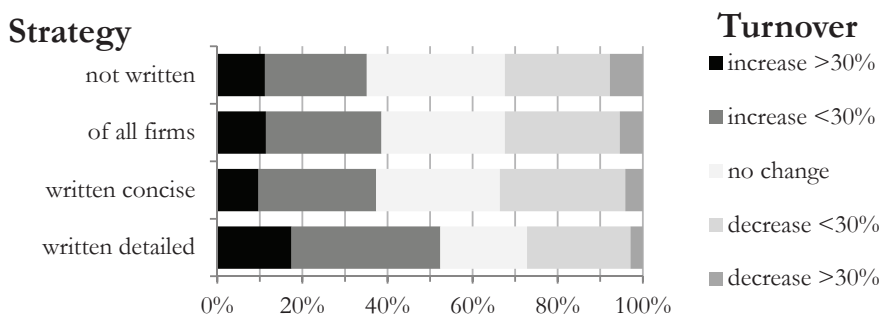

Fig. 4 - Strategy form and its influence on enterprise turnover trend (QB1/QC1). Source: own processing.

Figure 4 depicts how form of strategy influenced trend in average annual turnover. Only $35 \%$ of enterprises with not written strategy indicated growth of annual turnover in comparison to $53 \%$ of enterprises with detailed written strategy who indicated growth of annual turnover. The difference is almost $18 \%$ with advantage to them who have detailed written strategy. The phenomenon is not visible by companies with only concise strategy, so that thorough analyses and strategic plans are necessary.

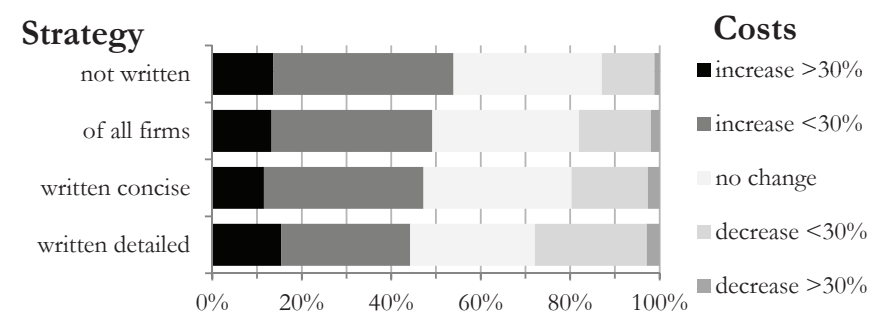

Fig. 5 - Strategy form and its influence on enterprise costs trend (QB1/QC2). Source: own processing.

Similar logic of trends and even more convincing numbers shows Figure 5 on the costs of enterprises. Number of $54 \%$ of enterprises with not written strategy indicated growth of costs in comparison to $44 \%$ of enterprises with detailed written strategy who indicated growth of costs. The difference is about $10 \%$ with advantage to them who have detailed written strategy. In other hand $13 \%$ of enterprises with not written strategy indicated fall of costs in comparison to $28 \%$ of enterprises with detailed written strategy who indicated fall of costs. The difference is now about $15 \%$ with advantage to them who have detailed written strategy. The phenomenon is partly visible by companies with only concise strategy too. 


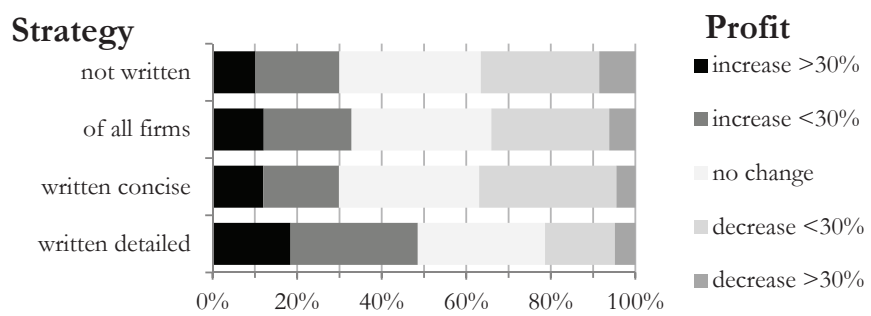

Fig. 6 - Strategy form and its influence on enterprise profit trend (QB1/QC3). Source: own processing.

The Figure 6 is some kind of "control question", as we know that profit = turnover - costs. We see pretty similar results: $30 \%$ of enterprises with not written strategy indicated growth of business profit in comparison to $49 \%$ of enterprises with detailed written strategy who indicated growth of profit. The difference is about $19 \%$ with advantage to them who have detailed written strategy. In other hand $37 \%$ of enterprises with not written strategy indicated fall of profit in comparison to $21 \%$ of enterprises with detailed written strategy who indicated fall of business profit. The difference is now about $16 \%$ with advantage to them who have detailed written strategy. The phenomenon is again not visible by companies with only concise strategy, who have approximately the same results as these with no written strategy.

Further three performance parameters were evaluated with the influential relation of strategy form (EVA, investments and arranged contracts):

I. (QB1/QC12) EVA (economic value added) comprising operating profit after tax (NOPAT), weighted average cost of capital (WACC) and employed economic capital is another view on enterprise profit. The $26 \%$ of enterprises with not written strategy indicated growth of EVA in comparison to $45 \%$ of enterprises with detailed written strategy who indicated growth of EVA. The difference is about $19 \%$ with advantage to them who have detailed written strategy. In other hand $20 \%$ of enterprises with not written strategy indicated fall of EVA in comparison to $22 \%$ of enterprises with detailed written strategy who indicated fall of EVA. The difference is now only $2 \%$ with advantage to them who have detailed written strategy.

II. (QB1/QC4) Extent of property investments (newly purchased assets) with relation to strategy form: The $31 \%$ of enterprises with not written strategy indicated increase of investments in comparison to $53 \%$ of enterprises with detailed written strategy who indicated increase of investments. The difference is about $22 \%$ with advantage to them who have detailed written strategy. In other hand $13 \%$ of enterprises with not written strategy indicated fall of investments in comparison to $17 \%$ of enterprises with detailed written strategy who indicated fall of investments. The difference is about $4 \%$ with advantage to them who have detailed written strategy. We can see that thorough strategic planning positively influences investments.

III. (QB1/QC6) Period of forward arranged contracts with relation in strategy form: Enterprises with not written strategy have in all cases shorter period of arranged contacts in comparison to them with at least concise strategy and significantly shorter in comparison to them with detailed written strategy. For example only $21 \%$ of enterprises with not written strategy indicated contracts over 1 year in comparison to $47 \%$ of enterprises with detailed written strat- 
egy who indicated contracts arranged over 1 year. The difference is about $26 \%$ with advantage to them who have detailed written strategy which is really high. Further $41 \%$ of enterprises with not written strategy indicated contracts arranged over 6 months in comparison to $67 \%$ of enterprises with detailed written strategy who indicated contracts arranged over 6 months. The difference is now also $26 \%$ with advantage to them who have detailed written strategy.

As we can clearly see, the existence of written strategy has significance in all observed business performance parameters.

\subsection{Strategy form vs. performance indicators evaluation summary}

Table 1 summarizes data graphically depicted above in Figures 4 to 6 and from further three performance parameters, so that hypotheses can be clearly evaluated. Differential analysis is utilized.

First two columns show particular performance parameters and their change categories (with exception of parameter C6, which shows time periods of future arranged contracts). Next four columns show forms of strategy and theirs percent rate regarding parameter change group. Total of all change groups (increase $>30 \%$, increase up to $30 \%$, no change, decrease up to $30 \%$, decrease $>30 \%$ ) in one particular form of strategy (detailed, concise, not written and of all firms) gives $100 \%$. Maximal (bigger bold font, darker background) and minimal (smaller font, lighter background) values in every parameter change group is highlighted, so it is well visible, which strategy form leads most and less to particular change value of parameter. Checking column "of all firms" gives always average values.

Tab. 1 - Impact of strategy forms on business performance according selected parameters including differential data analysis. Source: own processing.

\begin{tabular}{|c|c|c|c|c|c|c|c|c|c|}
\hline \multicolumn{2}{|c|}{ business strategy: } & \multirow{2}{*}{\begin{tabular}{|c|}
$\begin{array}{c}\text { written } \\
\text { detailed }\end{array}$ \\
$17,5 \%$ \\
\end{tabular}} & \multirow{2}{*}{\begin{tabular}{|c|}
$\begin{array}{c}\text { written } \\
\text { concise }\end{array}$ \\
$9,7 \%$ \\
\end{tabular}} & \multirow{2}{*}{$\begin{array}{c}\begin{array}{c}\text { of all } \\
\text { firms }\end{array} \\
11,4 \% \\
\end{array}$} & \multirow{2}{*}{$\begin{array}{c}\begin{array}{c}\text { not } \\
\text { written }\end{array} \\
11,2 \% \\
\end{array}$} & \multicolumn{2}{|c|}{$\begin{array}{c}\Delta \text { detailed - not } \\
\text { written }\end{array}$} & \multicolumn{2}{|c|}{$\begin{array}{c}\Delta \text { concise - not } \\
\text { written } \\
\end{array}$} \\
\hline \multirow{5}{*}{ C1: turnover } & increase $>30 \%$ & & & & & $6,3 \%$ & up & $-1,5 \%$ & up \\
\hline & increase $<30 \%$ & $35,0 \%$ & $27,6 \%$ & $27,2 \%$ & $23,9 \%$ & $11,0 \%$ & $17,3 \%$ & $3,7 \%$ & $2,2 \%$ \\
\hline & no change & $20,4 \%$ & $29,1 \%$ & $29,0 \%$ & $32,4 \%$ & $-12,0 \%$ & & $-3,3 \%$ & \\
\hline & decrease $<30 \%$ & $24,3 \%$ & $29,5 \%$ & $27,0 \%$ & $24,7 \%$ & $-0,4 \%$ & down & $4,8 \%$ & down \\
\hline & decrease $>30 \%$ & $2,9 \%$ & $4,1 \%$ & $5,4 \%$ & $7,7 \%$ & $-4,8 \%$ & $-5,2 \%$ & $-3,6 \%$ & $1,1 \%$ \\
\hline \multirow{5}{*}{ C2: costs } & increase $>30 \%$ & $15,4 \%$ & $11,5 \%$ & $13,2 \%$ & $13,7 \%$ & $1,7 \%$ & up & $-2,1 \%$ & up \\
\hline & increase $<30 \%$ & $28,8 \%$ & $35,7 \%$ & $35,9 \%$ & $40,2 \%$ & $-11,4 \%$ & $-9,7 \%$ & $-4,5 \%$ & $-6,7 \%$ \\
\hline & no change & $27,9 \%$ & $33,1 \%$ & $32,8 \%$ & $33,2 \%$ & $-5,3 \%$ & & $-0,1 \%$ & \\
\hline & decrease $<30 \%$ & $25,0 \%$ & $17,1 \%$ & $16,1 \%$ & $11,7 \%$ & $13,3 \%$ & down & $5,4 \%$ & down \\
\hline & decrease $>30 \%$ & $2,9 \%$ & $2,6 \%$ & $2,0 \%$ & $1,2 \%$ & $1,7 \%$ & $15,0 \%$ & $1,4 \%$ & $6,8 \%$ \\
\hline \multirow{5}{*}{ C3: profit } & increase $>30 \%$ & $18,4 \%$ & $11,9 \%$ & $12,1 \%$ & $10,1 \%$ & $8,3 \%$ & up & $1,8 \%$ & up \\
\hline & increase $<30 \%$ & $30,1 \%$ & $17,9 \%$ & $20,8 \%$ & $19,8 \%$ & $10,3 \%$ & $18,6 \%$ & $-1,9 \%$ & $-0,1 \%$ \\
\hline & no change & $30,1 \%$ & $33,2 \%$ & $33,0 \%$ & $33,5 \%$ & $-3,4 \%$ & & $-0,3 \%$ & \\
\hline & decrease $<30 \%$ & $16,5 \%$ & $32,5 \%$ & $27,9 \%$ & $28,0 \%$ & $-11,5 \%$ & down & $4,4 \%$ & down \\
\hline & decrease $>30 \%$ & $4,9 \%$ & $4,5 \%$ & $6,2 \%$ & $8,6 \%$ & $-3,7 \%$ & $-15,2 \%$ & $-4,1 \%$ & $0,4 \%$ \\
\hline
\end{tabular}




\begin{tabular}{|c|c|c|c|c|c|c|c|c|c|}
\hline \multirow{5}{*}{ C12: EVA } & increase $>30 \%$ & $15,6 \%$ & $6,3 \%$ & $8,5 \%$ & $6,2 \%$ & $9,4 \%$ & up & $0,1 \%$ & up \\
\hline & increase $<30 \%$ & $29,2 \%$ & $18,1 \%$ & $20,5 \%$ & $20,1 \%$ & $9,1 \%$ & $18,5 \%$ & $-2,0 \%$ & $-1,9 \%$ \\
\hline & no change & $33,3 \%$ & $51,7 \%$ & $49,4 \%$ & $54,1 \%$ & $-20,7 \%$ & & $-2,4 \%$ & \\
\hline & decrease $<30 \%$ & $19,8 \%$ & $21,4 \%$ & $18,8 \%$ & $16,3 \%$ & $3,5 \%$ & down & $5,2 \%$ & down \\
\hline & decrease $>30 \%$ & $2,1 \%$ & $2,5 \%$ & $2,8 \%$ & $3,3 \%$ & $-1,3 \%$ & $2,3 \%$ & $-0,8 \%$ & $4,3 \%$ \\
\hline \multirow{5}{*}{ C4: investments } & increase $>30 \%$ & $21,0 \%$ & $8,6 \%$ & $11,7 \%$ & $10,8 \%$ & $10,2 \%$ & up & $-2,2 \%$ & up \\
\hline & increase $<30 \%$ & $32,0 \%$ & $24,6 \%$ & $24,1 \%$ & $20,0 \%$ & $12,0 \%$ & $22,2 \%$ & $4,6 \%$ & $2,4 \%$ \\
\hline & no change & $30,0 \%$ & $46,1 \%$ & $47,6 \%$ & $55,8 \%$ & $-25,8 \%$ & & $-9,7 \%$ & \\
\hline & decrease $<30 \%$ & $16,0 \%$ & $18,0 \%$ & $14,1 \%$ & $10,4 \%$ & $5,6 \%$ & down & $7,6 \%$ & down \\
\hline & decrease $>30 \%$ & $1,0 \%$ & $2,7 \%$ & $2,6 \%$ & $2,9 \%$ & $-1,9 \%$ & $3,7 \%$ & $-0,2 \%$ & $7,4 \%$ \\
\hline \multirow{5}{*}{ C6: contracts } & $<1$ week & $3,0 \%$ & $9,3 \%$ & $11,1 \%$ & $15,4 \%$ & $-12,4 \%$ & & $-6,1 \%$ & \\
\hline & $<1$ month & $12,0 \%$ & $20,8 \%$ & $19,2 \%$ & $19,9 \%$ & $-7,9 \%$ & & $0,9 \%$ & \\
\hline & $<3$ months & $18,0 \%$ & $19,7 \%$ & $21,4 \%$ & $24,1 \%$ & $-6,1 \%$ & & $-4,4 \%$ & \\
\hline & $<6$ months & $20,0 \%$ & $23,6 \%$ & $20,9 \%$ & $19,9 \%$ & $0,1 \%$ & & $3,6 \%$ & \\
\hline & year and more & $47,0 \%$ & $26,6 \%$ & $27,4 \%$ & $20,7 \%$ & $26,3 \%$ & & $5,9 \%$ & \\
\hline
\end{tabular}

Last four columns show results of differential analysis. Differences between values of "written detailed" and "not written" in column 7 respective "written concise" and "not written" in column 9 clearly characterize the effect of written strategy. Positive values show percentage gain of written strategy and negative percentage loss of written strategy. Difference values signed as "up" (increase) and "down" (decrease) in columns 8 and 10 are calculated as the sum of increases/decreases over and up to $30 \%$. Grey values in right part of the table emphasize better performance of written strategies from the economic perspective.

We can see that in case of "written detailed" strategy there are 8 of 10 values better: higher grow of turnover, profit, EVA and investments; lower fall of turnover and profit - in case of costs higher fall and lower grow. Also contracts are clearly arranged for longer period - six months and more. Hypothesis $\mathbf{H} \mathbf{2}$ can be accepted: Existence of detailed written strategy of the organization has definite positive effect on selected business performance indicators confirmed by $80 \%$ of evaluated performance parameters.

We can also see that in case of "written concise" strategy there are only 4 of 10 values better: higher grow of turnover and investments - in case of costs higher fall and lower grow. Also contracts are mostly arranged for longer period - six months and more, but period 1 week to 1 month was also slightly strengthened. Hypothesis $\mathbf{H 3}$ cannot be accepted: Existence of brief, concise, not sufficiently detailed written strategy of the organization has not positive effect on $60 \%$ selected business performance indicators especially in the case of profit and EVA, where rough analyses and planning is insufficient. The strong positive effect is seen on costs; grow of turnover and investments and period of forward arranged contracts. 


\subsection{Pearson's chi-squared test of goodness of fit}

Following equation was used to calculate Pearson's chi-squared test of goodness of fit:

where:

$$
\chi^{2}=\sum_{i=1}^{n} \frac{\left(O_{i}-E_{i}\right)^{2}}{E_{i}}
$$

$\chi_{2} \ldots$ Pearson's cumulative test statistic,

$O_{i} \ldots$ an observed frequency,

$E_{i} \ldots$ an expected (theoretical) frequency,

$n \ldots$ the number of categories.

There were not possible reliably calculate Pearson's chi-squared test of goodness of fit of observed (selected) data to number of employees size structure of economical subjects in Czech Republic or Moravian-Silesian Region due to inaccurateness of accessible statistical data. Data obtained from public database of Czech Statistical Office "Economic subjects according NACE branch and number of employees" include 2639088 economic subjects and only 1534044 of them (58\%) contains information about number of employees (CZSO, 2013). With that inaccuracy was value of Pearson's chi-squared test of goodness of fit calculated on 7207, which is with 5 degrees of freedom strongly unacceptable on level of statistical significance 0,05 . Similar huge inaccuracy $(\sim 40 \%)$ provided statistical data accessible for Moravian-Silesian Region and from Albertina Data databases. Therefore we cannot decide if our observed data have representative value for whole Moravian-Silesian or Czech Republic milieu or not.

Another approach was utilized to calculate Pearson's chi-squared test of goodness of fit to Chisquared or Poisson distribution. The results can be seen on Figure 7. The value of Pearson's chi-squared test of goodness of fit to Chi-squared distribution was calculated on 287, which is with 5 degrees of freedom unacceptable on level of statistical significance 0,05 . The value of Pearson's chi-squared test of goodness of fit to Poisson distribution was calculated on 664, which is with 5 degrees of freedom also unacceptable on level of statistical significance 0,05 . The acceptable value with 5 degrees of freedom on level of statistical significance 0,05 for Chisquared distribution is not more than 11,1 . We can see that Chi-squared distribution fits more than Poisson distribution but not enough to be acceptable for statistical purposes. Nevertheless this fact does not depreciate presented findings because fitting number of employees' data into special distribution function has no any apparent practical significance and was calculated only for statistical reasons. 


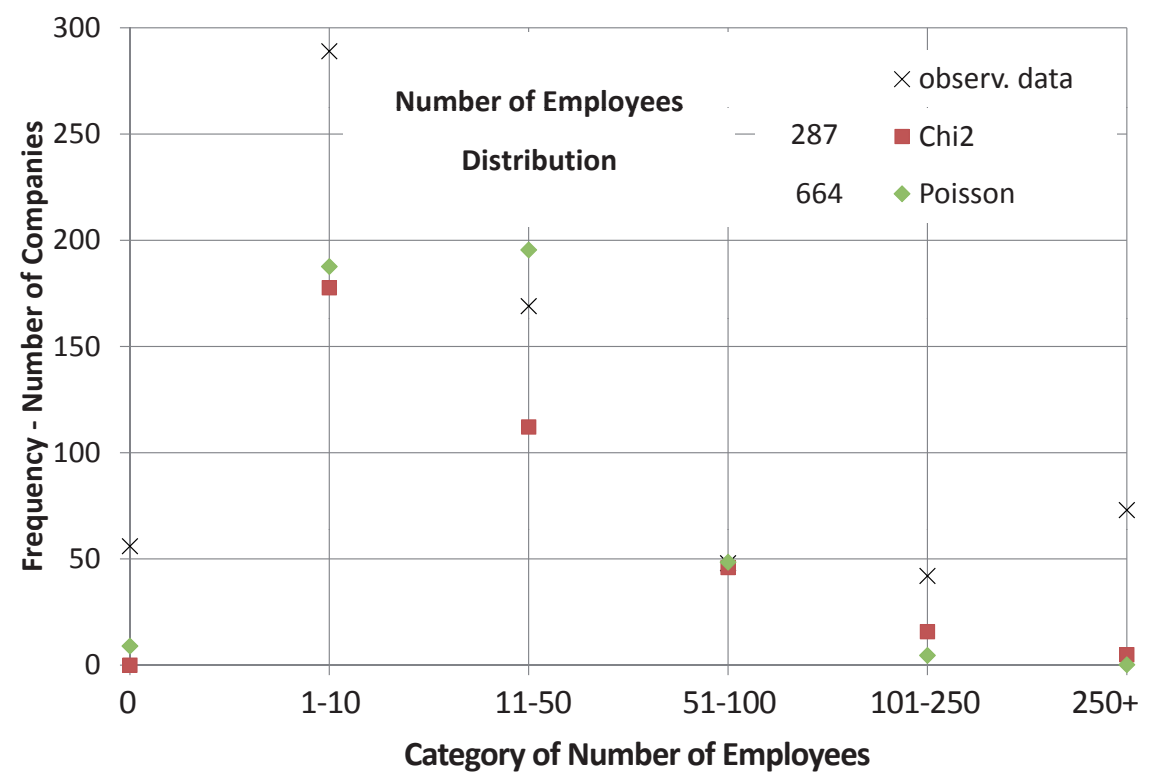

Fig. 7 - Frequencies of observed data "number of employees" versus Chi-squared and Poisson distribution functions.

Numbers near legend gives values of Pearson's chi-squared test of goodness of fit. Source: own processing.

Hypothesis H4 cannot be accepted: Selected data group criterion "number of employees" is not in concordance to Chi-squared or Poisson distribution according to Pearson's chi-squared test of goodness of fit.

\section{CONCLUSION}

Presented paper is focused on importance of strategic management and strategic planning for gaining competitive advance and better economic results. There were shown results of original questionnaire research performed mostly in SMEs of Moravian and Silesian region but also in other regions of Czech Republic and Slovakia. Data were characterized from the point of geographical view, the economic activity structure, period considered by strategy and the year of last strategy update. Strategy forms were confronted with size (number of employees and annual turnover), legal status and six selected performance parameters (turnover, costs, profit, EVA, investments and period of future arranged contracts). Four hypotheses were evaluated and short statistical calculation was proposed.

We can summarize most important finding of presented item like that: Bigger companies pay more attention to strategic management and have more often prepared detailed strategy than smaller enterprises. The merit of that paper lies in empiric recognition that thorough (detailed) strategic planning is definitely reasonable activity of any company, since enterprises who did prepare detailed strategic document proved in $80 \%$ of observed performance parameters better results than enterprises without written business plan. Enterprises who did prepare brief, partial, concise strategic document proved only in $40 \%$ of observed performance parameters 
better results than enterprises without written business plan, so there is necessary to put impact on proper strategic planning in all significant business areas. Our findings are supported by Parnell (2013), who confirms that retail SMEs with high strategic clarity will outperform those with moderate strategic clarity, but SMEs with low strategic clarity outperformed those with moderate strategic clarity.

The limitations of the paper are based in limited geographical scope of obtained data. Unfortunately we were not able to cover all regions of Czech Republic respective Slovakia with comparable sample size. In other hand the size of data group is relatively large. Shortcomings of utilized methodology are also in frequency of size groups, where we've got mostly micro and small enterprises (10 to 50 employees). And finally we were not able to check statistical significance of sample group with official statistical data due their inaccuracy. These limitations nevertheless in our opinion do not outclass importance of presented findings, which come from real life conditions.

\section{Acknowledgement}

The article was published with the support of the Grant Agency of the Czech Republic: Project Eurocores, grant number ECRP/11/E025 and the Student Grant System, Silesian University in Opava, grant number: SGS/9/2012.

\section{References}

1. Analoui, F., \& Karami, A. (2003). Strategic management: In small and medium enterprises. London: Thomson Learning.

2. Andersen, T. J. (2000). Strategic Planning, Autonomous Actions and Corporate Performance. Long Range Planning, 33(2), 184-200. http://dx.doi.org/10.1016/S00246301(00)00028-5

3. CZSO, Czech Statistical Office (2013). Public database [online]. Retrieved November 20, 2013 from: http://vdb.czso.cz/vdbvo/uvod.jsp.

4. David, F.R. (2013). Strategic Management. Concepts and Cases. Harlow: Pearson Education Ltd.

5. EC, European Commission (2012). EU SMEs in 2012: at the crossroads. Annual report on small and medium-sized enterprises in the EU. 2011/12 [online]. Ecorys for European Commission, Rotterdam. Retrieved March 12, 2013 from: http://ec.europa.eu.

6. Glaister, K. W., \& Dincer, O. et al. (2008). A causal analysis of formal strategic planning and firm performance - Evidence from an emerging country, Emerald, Management Decision, 46(3-4), 365-391.

7. Johnson, G., Scholes, K., \& Whittington, R. (2006). Exploring Corporate Strategy. Harlow: Pearson Education Ltd.

8. Kotler, P., \& Keller, K. L. (2007). Marketing Management. Praha: Grada Publishing.

9. Mallya, T. (2007). Základy strategickébo rízené a roz̧odování. Praha: Grada Publishing. 
10. MPO, Ministerstvo průmyslu a obchodu (2012). Zpráva o vývoji malého a strédního podnikáni a jeho podpoře v roce 2011 [online]. Ministerstvo průmyslu a obchodu (MPO). Retrieved March 14, 2012 from: http://www.komora.cz.

11. Parnell, J. A. (2013). Uncertainty, Generic Strategy, Strategic Clarity, and Performance of Retail SMEs in Peru, Argentina, and the United States. Journal of Small Business Management, 51(2), 215-234. http://dx.doi.org/10.1111/jsbm.12010

12. Pawliczek, A., Rylková, Ž., Šebestová, J., Antonová, B., Piszczur, R., \& Veselá, K. (2011). Adaptibilita podnikéni v reakici na turbulentní politicko-ekonomické prostrédí a technologický pokrok. $v$ kontextu udržitelného rozvoje [Unpublished Reviewed Research Report]. Karviná: OPF SU Karviná, Silesian University Opava.

13. Rudd, J. M., Greenley, G. E., Beatson, A. T., \& Lings, I. N. (2008) Strategic planning and performance: Extending the debate. Journal of Business Research, 61(2), 99-108. http://dx.doi. org/10.1016/j.jbusres.2007.06.014

14. Skokan, K. (2010). Inovační paradox a regionální inovační strategie. Journal of Competitiveness, 2(2), 30-46.

15. Song, M., Im, S., Bij, H., \& Song, L. Z. (2011). Does Strategic Planning Enhance or Impede Innovation and Firm Performance. Journal of Product Innovation Management, 28(4), 503-520. http://dx.doi.org/10.1111/j.1540-5885.2011.00822.x

16. Šebestová, J., \& Nowáková, K. (2013). Dynamic strategy for sustainable business development: mania or hazard? The Amfiteatru Economic Journal, 15(34), 442-454.

17. Volberda, H. W et al. (2010). Strategic Management: Competitiveness and Globalization (Concepts and Cases). Andover: Cengage Learning EMEA.

18. Zich, K. (2010). Koncepce úspěchuschopnosti a její pojetí strategie. E+M Economics and Management, 13(1), 60-73.

\section{Contact information}

prof. Ing. Karel Skokan, Ph.D.; Ing. Radomír Piszczur

School of Business Administration in Karviná, Silesian University in Opava

Univerzitni námèstí 1934/3, 73340 Karviná, Cžech Republic

Email:skokan@opf.slu.cz; rpiszczur@post.cz.

Ing. Adam Pawliczek, Ph.D.

Moravian University College Olomouc

Tr. Kosmonauti 1288/1, Hodolany, 77900 Olomouc

Email:pawliad@seznam.cz. 